\title{
EVALUASI PROGRAM DESA MANDIRI ANGGUR MERAH (ANGGARAN UNTUK RAKYAT MENUJU SEJAHTERA) DI KECAMATAN LAMBOYA KABUPATEN SUMBA
}

\author{
Frengky Niga Awang ${ }^{1}$, Retno Sunu Astuti ${ }^{2}$
}

\begin{abstract}
The Government's commitment to empowering the Autonomous Region to eradicate poverty today is very beneficial to the development of a region, but the commitment must be coupled with the willingness of the local government concerned and appropriate policies. The policy of the Red Grass Village Program in the form of providing capital to the community in the form of farmer groups in Lamboya Sub-district is a form of government commitment to eradicate poverty in the area. The problem that occurred in the policy of Red Mandiri Anggur Village Program is that the policy does not reduce the poverty rate, does not encourage the empowerment of village institutions, and the absence of new entrepreneurs. The purpose of this study is to evaluate the success of the red wine village self-service program policy by looking at Willyam Dunn's evaluation indicators of effectiveness, responsiveness, and accuracy. And to analyze the factors inhibiting the success of Dedy Mulyadi policy that is the content of policies, implementers, and environment. This research uses qualitative approach with purposive technique to determine key informant. The results of the evaluation indicate that the policy of Mandiri Anggur Merah Village Program in Lamboya Sub-district of West Sumba Regency has not succeeded in reducing the poverty level after the policy, unsuccessful to encourage the empowerment of village institutions and the creation of new entrepreneurs. While the obstacles to the success of the policy are the lack of clear policy content such as organizing, the implementation of less socialized programs to the community and the lack of support from the community and government.
\end{abstract}

Keywords: Policy Evaluation, Independent Village Program, Empowerment, HR Capability

\section{PENDAHULUAN}

Penyelenggaraan Pemerintahan Daerah sebagaimana yang telah diamanatkan di dalam Undang - Undang Dasar Negara Republik Indonesia Tahun 1945 pasal 18 ayat (2) menyatakan bahwa pemerintahan daerah provinsi, daerah kabupaten dan kota mengatur dan mengurus sendiri urusan pemerintahan menurut asas otonomi dan tugas pembantuan, diarahkan untuk memenuhi kepen-tingan bangsa secara keseluruhan demi mewujudkan

\footnotetext{
${ }^{1}$ Kecamatan Lamboya, Kabupaten Sumba, Nusa Tenggara Barat, Indonesia

${ }^{2}$ Magister Administrasi Publik, Fakultas IImu Sosial dan IImu Politik, Universitas Diponegoro
} 
cita-cita masyarakat lebih baik, masyarakat yang lebih adil dan makmur. Hal itu seperti yang disebutkan dalam Pembukaan Undang - Undang Dasar Negara Republik Indonesia Tahun 1945, yaitu melindungi segenap bangsa Indonesia dan seluruh tumpah darah Indonesia, dan untuk memajukan kesejahteraan umum, mencerdaskan kehidupan bangsa dan ikut melaksanakan ketertiban dunia yang berdasarkan kemerdekaan, perdamaian abadi dan keadilan sosial.

Salah satu penghambat pembangunan ekonomi adalah kemiskinan yang merupakan tolak ukur bagi sebuah negara apakah pembangunan yang tengah berlangsung dapat dinikmati oleh segenap warga negaranya tanpa memandang hal-hal yang bersifat atributif. Dengan kata lain, pembangunan yang berlangsung benar-benar merata dalam masyarakat. Kemiskinan masih merupakan masalah sosial yang dihadapi Negara Kesatuan Republik Indonesia hingga kini. Hal itu dapat dilihat dari tingginya tingkat kemiskinan di Indonesia sampai ke daerah-daerah. Jumlah penduduk miskin di Indonesia pada September 2015 mencapai 28,51 juta orang (11,13 persen), menurun 0,08 juta orang dibandingkan dengan penduduk miskin pada Maret 2015 yang sebanyak 28,59 juta orang $(11,22$ persen $)$.

Mencermati tingginya angka kemiskinan tersebut, dapat disimpulkan upaya pemerintah baik pemerintah pusat maupun Pemerintah Daerah dalam mengentaskan kemiskinan belum membuahkan hasil yang maksimal. Masalah tersebut menjadi tantangan besar bagi pemerintah sebagai penerima amanat Pancasila dan Undang-Undang Dasar Negara Republik Indonesia Tahun 1945.

Di tengah menjamurnya program-program pemberdayaan dan pengentasan kemiskinan di Pedesaan, pemerintah Provinsi Nusa Tenggara Timur juga mengeluarkan kebijakan program yang hampir serupa dengan program yang diberikan oleh pemerintah pusat, yaitu Program Desa Mandiri Anggur Merah (Anggaran Untuk Rakyat Menuju Sejahtera), Program Anggur Merah merupakan kebijakan sebagai upaya untuk pengentasan kemiskinan melalui pengembangan usaha ekonomi produktif dengan pendekatan pemberdayaan berdasarkan potensi yang ada pada masyarakat desa. Dalam Peraturan Gubernur NTT Nomor 33 Tahun 2010 tentang Pedoman Pembangunan Desa Mandiri “Anggur Merah" disebutkan bahwa; pemerintah provinsi mengalokasikan fresh money sebesar 250 juta yang bersumber dari APBD untuk setiap desa dan setiap desanya didampingi oleh satu orang pendamping. 
Tujuan dari program ini adalah Pertama, mengurangi angka kemis-kinan melalui pengembangan usaha ekonomi produktif desa sesuai keunggulan kompetitif/komparatif desa, berupa pemberian dana hibah kepada pemerintah desa/kelurahan untuk disalurkan dalam bentuk pinjaman kepada kelompok usaha ekonomi masyarakat (pokmas) dan koperasi. Untuk keberlangsungan program, pengembalian atas pinjaman dari pokmas digulirkan kembali kepada pokmas yang lain sehingga program dari tahun 2011 s.d. 2014, dana Program Desa Mandiri Anggur Merah telah disalurkan oleh pemerintah desa/ kelurahan kepada 10.103 pokmas/ koperasi dengan berbagai jenis usaha, antara lain peternakan, pertanian, perikanan, usaha kecil, perdagangan, dan koperasi simpan pinjam. Kedua, Program Desa Mandiri Anggur Merah juga bertujuan untuk mendorong pemberdayaan kelembagaan desa/ kelurahan untuk mendukung pelaksanaan tekad pembangunan dan agenda pembangunan daerah sesuai RPJMD Provinsi NTT. Ketiga Menciptakan calon wirausahawan baru yang dapat membuka lapangan kerja baru yang dapat meningkatkan produktivitas tenaga kerja di Desa/Kelurahan. Penyelenggaraan pembangunan di Kabupaten Sumba Barat menemui beberapa permasalahan, sebagai berikut; Pertama, tingginya angka kemiskinan. Badan Pusat Statistik menunjukkan bahwa jumlah penduduk miskin di Kabupaten Sumba Barat pada tahun 2015 sebesar: 37.35 ribu jiwa atau $30.56 \%$.

Kedua, rendahnya kualitas sumber daya manusia. Kemiskinan berimpli-kasi pada rendahnya kualitas sumber-daya manusia di Kabupaten Sumba Barat karena dengan kondisi tersebut masyarakat tidak mampu memperoleh pendidikan formal yang baik sehinggga SDM masyarakat masih rendah dan kondisi kesehatan masyarakat yang buruk. Ketiga, masalah rawan bencana alam. Wilayah Kabupaten Sumba Barat sering dilanda bencana, tanah longsor dan kekeringan yang mengakibatkan kerusakan pada lahan pertanian masyarakat.

Tujuan dari penelitian ini adalah Mengevaluasi Keberhasilan Program Desa Mandiri Anggur Merah di Kecamatan Lamboya Kabupaten Sumba Barat. Menganalisis faktor pendukung dan menghambat keber-hasilan penyelenggaraan Program Desa Mandiri Anggur Merah di Kecamatan Lamboya kabupaten Sumba Barat.

Sebelum membahas lebih lanjut program tersebut perlu diulas pengertian tentang kebijakan publik. William N. Dunn (dalam Pasolong, 2007:39) mengemukakan kebijakan publik sebagai suatu rangkaian pilihan-pilihan yang saling berhubungan yang dibuat oleh 
lembaga atau pejabat pemerintah pada bidang-bidang yang menyangkut tugas pemerintahan, seperti pertahanan keamanan, energi, kesehatan, pendidikan, kesejahteraan masyarakat, kriminalitas, perkotaan, dan lain-lain.

Pengertian lain tentang kebijakan publik dijelaskan oleh Thomas R. Dye (dalam Winarno, 2014:20) yang mengatakan bahwa kebijakan publik adalah apapun yang dipilih oleh pemerintah untuk dilakukan dan tidak dilakukan.

Suatu kebijakan yang telah dibuat perlu juga dilakukan evaluasi. Evaluasi secara sederhana merupakan kegiatan untuk mengetahui apakah suatu program dilaksanakan sesuai apa yang diinginkan dan apabila tidak sesuai apa yang perlu kita lakukan. Apakah kita menghentikan kebijakan atau memperbaikinya. Proses penyelidikan inilah merupakan titik berat evaluasi. (Moekijat, 1995:180).

Sementara itu, Jones (dalam Widodo, 2007:113) mengatakan bahwa evaluasi kebijakan publik adalah suatu aktivitas yang dirancanag untuk menilai hasil-hasil kebijakan pemerintah yang mempunyai perbedaan yang sangat penting dalam spesifikasi objeknya, teknik-teknik pengukuran dan metode analisisnya.

Pengukuran dan penilaian evaluasi sebuah keberhasilan kebijakan memerlukan kriteria atau indikator agar pengukuran atau penilaian yang dilakukan lebih objektif. Teori yang digunakan untuk mengupas perma-salahan kebijakan pembangunan rumah keluarga belum beruntung di Kecamatan Lamboya Kabupaten Sumba Barat adalah teori evaluasi yang dicetuskan oleh Willyam N. Dunn (dalam Subarsono, 2008:126)

Indikator evaluasi menurut Dunn meliputi: pertama, efektivitas berkenan dengan apakah hasil yang diinginkan telah tercapai? Dalam artian bahwa ukuran efektivitas merupakan suatu standar akan terpenuhinya mengenai sasaran dan tujuan yang akan dicapai. Selain itu, menunjukan pada tingkat sejauhmana organisasi, program/ kegiatan melaksanakan fungsi-fungsinya secara optimal.

Kedua Responsivitas, berkenan dengan apakah hasil kebijakan memuat preferensi/nilai kelompok dan dapat memuaskan mereka? Dalam artian bagaimana respon atau tanggapan masyarakat dari suatu aktivitas kebijakan. Ketiga Ketepatan, berkenan dengan apakah hasil yang dicapai bermanfaat dan tepat diberikan kepada masyarakat yang membutuhkan?

Dalam pelaksanaan kegiatan tidak selalu tujuan yang diinginkan bisa dicapai karena terdapat faktor yang mempengaruhi. Untuk menganalisis faktor penghambat keberhasilan 
kebijakan, penulis menggunakan evaluasi keberhasilan kebijakan yang dkemukakan oleh Mulyadi (2015:15), yakni: Pertama, Isi atau content kebijakan; berkenan dengan isi kebijakan yang jelas tentang pengorga-nisasian, pelaksanaan program dan didukung oleh sumberdaya finansial. Kedua, Implementator; berkenan dengan Implementator yang mempu-nyai kapabilitas dan kompetensi dalam melaksanakan kebijakan. Ketiga, Lingkungan; dalam artian bahwa suatu dukungan sistem politik sangat menentukan keberhasilan dalam pelaksanaan kebijakan.

Penelitian ini menggunakan jenis penelitian kualitatif, yaitu jenis penelitian yang digunakan untuk meneliti pada kondisi objek yang alamiah dengan membuat deskripsi atau lukisan secara sistematis dan akurat mengenai fakta, sifat, serta hubungan antara fenomena yang sedang diselidiki dan menjelaskan fenomena-fenomena yang terjadi yang berkaitan dengan penelitian yang di teliti. (Moleong, 2012:6).

Penelitian ini memfokuskan pada evaluasi program Anggur Merah di Kecamatan Lamboya Kabupaten Sumba Barat. Apakah sudah sesuai dengan tujuan program yang termuat dalam Pergub Nomor 33 Tahun 2010. Lokasi Pelaksanaan penelitian dilaksanakan di Kecamatan Lamboya, Kabupaten Sumba Barat. Adanya pembatasan lokasi dalam penelitian ini bertujuan agar peneliti dapat lebih mudah dalam mengamati permasalahan atau fenomena yang ada secara mendalam. Untuk itu diperlukan informaninforman penelitian, yaitu orang yang benar-benar tahu atau pelaku yang terlibat langsung dengan dengan permasalahan penelitian. Prasyarat dari informan adalah harus mempunyai banyak pengalaman tentang latar penelitian (Moleong, 2011:132). Hal ini menunjukan bahwa seorang informan haruslah benar-benar mengetahui tentang latar belakang permasalahan penelitian atau pelaku yang memiliki keterlibatan langsung dengan permasalahan penelitian.

Teknik pengumpulan data yang digunakan adalah wawancara, observasi dan studi dokumentasi. Data yang diperoleh dari informan selanjutnya akan dianalisis secara sistematis dengan melakukan tiga langkah secara bersamaan, yaitu reduksi data, penyajian dan penarikan kesimpulan/verifikasi. 


\section{PEMBAHASAN}

\section{Efektivitas}

Efektivitas dalam sebuah evaluasi kebijakan merupakan hal yang penting untuk mengetahui hasil sebuah kebijakan. Wahab, (2011:27) misalnya mengatakan bahwa untuk memahami makna kebijakan adalah dengan melihatnya dari sudut akhirnya, yaitu, dalam artian apa yang senyatanya telah dicapai.

Hasil yang diinginkan dalam kebijakan Program Desa Mandiri Anggur Merah Adalah mengentaskan kemiskinan atau menekan angka kemiskinan dengan memberikan modal atau bantuan untuk digunakan.

Kebijakan program desa mandiri di Kecamatan Lamboya Kabupaten Sumba Barat dinilai tidak sesuai yang diharapkan dalam tujuan kebijakan karena dari hasil penelitian kemiskinan di Kecamatan Lamboya tidak berkurang.

\section{$\underline{\text { Responsivitas }}$}

Menurut Dunn (dalam Subarsono, 2008:126) suatu hasil kebijakan dianggap baik jika ada keterlibatan masyarakat dalam kebijakan tersebut. Responsivitas dalam kebijakan Program Desa Mandiri Anggur Merah dapat dilihat sejauh mana program itu dapat menjawab kebutuhan masyarakat Lamboya dan bagaimana peran serta masyarakat dalam program.

Kebijakan Program Desa Mandiri Anggur Merah di Kecamatan Lamboya Kabupaten Sumba Barat menunjukkan bahwa respon masyarakat dengan program tersebut adalah baik dan menganggap bahwa program ini sesuai dengan kebutuhan masyarakat. Namun dalam pelaksanaannya di lapangan banyak mengalami kendala seperti kurangnya respon masyarakat terhadap pengembalian dana agar bisa digulirkan lagi pada kelompok lain. Partisipasi yang sangat rendah dari masyarakat membuat keberlangsungan program tersebut menuai kendala dalam hal pengguliran kepada kelompok lain.

\section{$\underline{\text { Ketepatan }}$}

Menurut Dunn (dalam Subarsono, 2008:45) kriteria yang dipakai menyeleksi sejumlah alternatif untuk dijadikan rekomendasi adalah dengan menilai apakah hasil dari alternatif yang direkomendasikan tersebut: merupakan pilihan tujuan yang layak serta merupakan pilihan tujuan yang layak. Ketepatan dalam kebijakan Program Anggur 
Merah merujuk pada tepatnya pemberian bantuan kepada masyarakat, apakah sudah sesuai dengan yang masyarakat butuhkan atau tidak.

Kebijakan Program Desa Mandiri Anggur Merah di Kecamatan Lamboya Kabupaten Sumba Barat dinilai tepat dalam pembagian bantuan kepada masyarakat, namun masih banyak warga yang belum mendapatkan bantuan tersebut karena sistem pengguliran dananya mengalami kemacetan di lapangan.

\section{Faktor Penghambat Keberhasilan Kebijakan Program Desa Mandiri Anggur Merah di Kecamatan Lamboya Kabupaten Sumba Barat.}

\section{$\underline{\text { Isi atau Content Kebijakan }}$}

Suatu kebijakan dapat berhasil atau tidak sangat ditentukan oleh isi kebijakan yang jelas dan tidak distorsi karena isi kebijakan merupakan arah berpikir, bahkan menjadi acuan dalam melaksanakan kebijakan. Isi kebijakan Program Desa Mandiri Anggur Merah adalah pada bagaimana pengorganisasian program, pelaksanaan program dan pembiayaan program.

Kebijakan Program Desa Mandiri Anggur Merah di Kecamatan Lamboya Kabupaten Sumba Barat menemui kendala dalam pelaksanaannya, seperti pengorganisasian kurang jelas dalam hal yang melaksanakan atau menangani program. Kendala lain adalah pelaksanaan program yang kurang disosialisasikan kepada masyarakat dengan baik sehingga sebagian masyarakat banyak yang tidak tahu proses pelaksanaan program.

\section{Implementor}

Implementator yang dimaksud dalam bahasan ini adalah implementator yang punya kapabilitas dan kompetensi. Dalam pelaksanaan Program Desa Mandiri Anggur Merah, kapabilitas seorang pendamping di lapangan kurang aktif dalam mendampingi kelompok masyarakat sehingga kontrol terhadap pengguliran dana tidak benar-benar dikelola dengan baik.

\section{Lingkungan}

Lingkungan yang dimaksud dalam bahasan ini adalah dukungan lingkungan masyarakat dalam kebijakan Program Desa Mandiri Anggur Merah. Saat penelitian menunjukkan adanya kurangnya kerja sama dan dukungan dari lingkungan masyarakat itu sendiri sehingga warga banyak yang tidak mampu bekerja sama dan saling mendukung 
dalam hal pengguliran dana. Pemerintah daerah juga kurang dalam mengembangkan program yang berjalan, lingkungan pemerintah dalam hal ini pemerintah desa kurang mendukung pelaksanaan program tersebut. Sementara itu, dari dukungan lingkungan politik, masyarakat tidak begitu mengetahuinya karena bagi masyarakat umum yang berada di kecamatan menganggap bahwa bantuan yang diberikan kepada mereka merupakan bantuan yang diprioritaskan kepada mereka, tanpa harus di kembalikan lagi atau digulirkan pada kelompok lain.

\section{PENUTUP}

Kebijakan Program Desa Mandiri Anggur Merah di Kecamatan Lamboya Kabupaten Sumba Barat tidak sesuai dengan yang diharapkan dalam tujuan kebijakan. Efektifitas dalam pelaksanaan program tidak berjalan dengan baik karena kurangnya kerja sama yang baik antara pemerintah dengan masyarakat. Masyarakat kurang paham tentang proses pengguliran dana serta cara mengembangkan dana yang sudah dibagikan sehingga proses pelaksanaan di setiap desa lebih banyak mengalami kegagalan.

Hasil penelitian menunjukkan, secara umum usaha kelompok masyarakat belum sepenuhnya berjalan secara optimal dalam membantu mengembangkan ekonomi pedesaan. Hal tersebut terjadi terutama karena belum adanya penerapan prinsip usaha bersama pada pokmas dan dana pinjaman yang diterima oleh anggota pokmas terlalu kecil sehingga tidak memadai untuk pengembangan usaha. Permasalahan tersebut juga mengakibatkan tingkat pengembalian pinjaman oleh pokmas kepada pemerintah desa/kelurahan relatif rendah sehingga pada gilirannya perguliran dana Desa mandiri Anggur Merah untuk pengembangan ekonomi desa belum berjalan secara optimal. Program Anggur Merah juga bertujuan untuk mendorong pemberdayaan kelembagaan desa/kelurahan untuk mendukung pelaksanaan tekad pembangunan dan agenda pemba-ngunan daerah sesuai RPJMD Provinsi NTT.

Dari hasil penelitian menunjukkan bahwa secara umum pemerintah desa dalam pelaksanaan Program Anggur Merah belum berperan secara optimal dalam proses penentuan dan penetapan kelompok masyarakat. Dalam proses perguliran dana dan pengawasan atas pokmas dalam pelaksanaannya, pemerintah desa lebih banyak 
bersifat pasif dan hanya mengandalkan Pendamping Kelompok Masyarakat sehingga tidak mengetahui perkembangan usaha pokmas secara pasti.

Dalam menciptakan calon wirausaha baru, belum ada satu pun pendamping Desa Mandiri Anggur Merah yang mampu merintis usaha di perdesaan sebagai pilot proyek percontohan pengembagan usaha ekonomi produktif, juga sekaligus mempekerjakan tenaga kerja lokal yang menjadi calon entrepreneur hasil tempaan program Desa Mandiri Anggur Merah.

Kebijakan Program Desa Mandiri Anggur Merah di Kecamatan Lamboya Kabupaten Sumba Barat tidak memenuhi unsur responsivitas. Hal itu ditandai dari kebijakan program tersebut menjadi suatu kebutuhan masyarakat Lamboya dalam hal mengentaskan kemiskinan. Selain itu, banyak masyarakat, bahkan keluarga sasaran tidak aktif dalam melakukan pengembalian dana program yang sudah dibagikan, untuk digulirkan kepada kelompok lain. Respon masyarakat pada umumnya terlihat pada proses awal pengguliran dana pada setiap kelompok masyarakat. Yang menjadi kendala utama adalah masyarakat tidak merespon balik dalam hal pengguliran dana untuk disalurkan pada kelompok lain.

Kebijakan Program Desa Mandiri Anggur Merah Kecamatan Lamboya Kabupaten Sumba Barat tidak memenuhi unsur ketepatan. Hal itu ditunjukan dari masyarakat, bahkan kelompok tani yang tidak mendapat-kan dana program, banyak terjadi salah sasaran. Pemberian Program dan pembagian dana program berdasarkan unsur kedekatan antara pengurus dan masyarakat serta tidak tepatnya pengembalian dana yang dipinjamkan.

Produk Kebijakan Program Desa Mandiri Anggur Merah di Kecamatan Lamboya pengorganisasiannya tidak jelas, seperti tidak dibentuknya pengurus pada tingkat desa sebagai panitia program. Pelaksanaan program juga tidak disosialisasikan dengan baik dan pembiayaan yang terkesan tidak mencukupi dalam pelaksanaan program.

Pelaksanaan kebijakan dalam Program Desa Mandiri Anggur Merah di Kecamatan Lamboya berpendidikan sarjana. Namun, dalam pelaksanaannya tidak sesuai dengan harapan di mana mereka sebagai implementator dalam mendampingi masyarakat di lapangan tidak menjalakan tugas dengan baik karena mengurus lebih dari satu desa. Kebijakan Program Desa Mandiri Anggur Merah di Kecamatan Lamboya juga 
dipengaruhi oleh lingkungan masyarakat itu sendiri. Warga masyarakat penerima dana program tidak saling mendukung, tingkat pendidikannya sangat minim, dan ketergantungan terhadap budaya sangat tinggi.

\section{DAFTAR PUSTAKA}

Badudu, J.S dan Sutan Mohammad Zain, 2001, Kamus Umum Bahasa Indonesia, Pustaka Sinar Harapan, Jakarta.

Buku Laporan Data Sosial Ekonomi Badan Pusat Statistik RI, 2016, Edisi 71.

Christopher P. Blocker, 2012, Memahami Kemiskinan dan Mempromosikan Pengentasan Kemiskinan, Journal of Business Research.

Data Badan Pusat Statistik Provinsi Nusa Tenggara Timur Tahun 2016.

Data Badan Pusat Statistik Kabupaten Sumba Barat 2010/2015.

Dunn, William N, 2003, Pengantar Analisis Kebijakan Publik, Gadjah Mada University Press, Yogyakarta.

Dwijowijoto, Riant Nugroho, 2004, Kebijakan Publik Formulasi, Implementasi dan Evaluasi, PT Elex Media Komputindo Kelompok Gramedia, Jakarta.

Dwijowijoto, Riant Nugroho, 2006, Analisis kebijakan, Alex Media, Jakarta.

Edwards III, George C, 1980, Implementing Public Policy, Congressional Quartely Press, Texas.

Islamy, M. Irfan, 1995, Prinsip-Prinsip Perumusan Kebijakan Negara, Sinar Grafika, Jakarta.

Juli Panglima Saragih, 2015, Analisis Kebijakan Pemerintah Dalam Pengentasan Kemiskinan di Daerah Istimewa Yogyakarta, TRANSPARANSI-Jurnal Ilmiah Ilmu Administrasi, nomor 02, Volume/edisi VII, Yogyakarta.

Moleong, Lexy, J, 2010, Metodelogi Peneltian Kualitatif, PT. Remaja Rosda Karya, Bandung.

Subarsono, AG, 2012, Analisis Kebijakan Publik, konsep, teori dan Aplikasi, Pustaka Pelajar, Yogyakarta.

Sugiono, 2015, Metode Penelitian Kualitatif dan R\&D, Alfabeta, Bandung.

Peraturan Gubernur Nusa Tenggara Timur Nomor 33 Tahun 2010 tentang Pedoman Pembangunan Desa/Kelurahan Mandiri Anggur Merah Provinsi NTT. 
Usman Sunyoto, 2010, Pembangunan dan Pemberdayaan Masyarakat, Pustaka Pelajar, Yogyakarta.

Undang-Undang Nomor 32 Tahun 2004 tentang Pemerintahan Daerah.

Peraturan Pemerintah Nomor 8 Tahun 2003 tentang Pedoman Organisasi Perangkat Daerah.

Yogyakarta. Center Of Akademic Publishing Service. 